\title{
FLAVONOIDS AND TRITERPENOIDS FROM CALLISTEMON CITRINUS AND THEIR INHIBITORY EFFECT ON NO PRODUCTION IN LPS-STIMULATED RAW264.7 MACROPHAGES
}

\author{
Nguyen Manh Cuong1, Pham Ngoc Khanh¹, Ho Viet Duc ${ }^{2}$, Tran Thu Huong ${ }^{1}$, \\ Youn-Chul Kim ${ }^{3}$, Pham Quoc Long ${ }^{1}$, Young Ho Kim ${ }^{4}$ \\ ${ }^{1}$ Institute of Natural Products Chemistry, Vietnam Academy of Science and Technology, 18 \\ Hoang Quoc Viet, Cau Giay, Hanoi \\ ${ }^{2}$ Faculty of Pharmacy, Hue University of Medicine and Pharmacy, Hue University, 06 Ngo \\ Quyen, Hue, Vietnam \\ ${ }^{3}$ College of Pharmacy, Wonkwang University, Iksan 570-749, Korea \\ ${ }^{4}$ College of Pharmacy, Chungnam National University, Daejeon 305-764, Korea \\ "Email: nmcuong_inpc@yahoo.com.vn
}

Received: 11 August 2015; Accepted for publication: 2 January 2016

\begin{abstract}
Phytochemical investigation of the leaves and stems of Callistemon citrinus (Curtis) Skeels led to the isolation of 12 flavonoid and triterpenoid compounds, including one new flavonoid, callistine A (1) and six known flavonoids, 6,7- dimethyl-5,7-dihydroxy-4'-methoxy flavone (2), astragalin (3), quercetin (4), catechin (5), eucalyptin (6), and 8-demethyleucalyptin (7), along with 5 known triterpenoids, 3- $\beta$-acetylmorolic acid (8), 3 $\beta$-hydroxy-urs-11-en-13(28)-olide (9), betulinic acid (10), diospyrolide (11) and ursolic acid (12). Their chemical structures were determined by analysis of their 1D- and 2D-NMR and HR-MS data. All isolated compounds were examined for their inhibitory activity against LPS-activated NO production in macrophage RAW264.7 cells. Among them, quercetin (4) and 3 $\beta$-hydroxy-urs-11-en-13(28)-olide (9) showed the most potent activities.
\end{abstract}

Keywords: Callistemon citrinus (Curtis) Skeels, flavonoid, triterpenoid, RAW264.7 macrophage.

\section{INTRODUCTION}

Nitric oxide (NO) is an important molecule. It acts as a defense factor against invading bacterial pathogens and is an essential element in the regulation of immune reactions [1]. While low concentrations of NO bring valuable benefits to the immune system to defend against pathogens, excessive amounts of NO can result in chronic inflammation and consequently various inflammatory disorders including cardiovascular, cancer, arthritis, autoimmune diseases, 
etc. [2]. Since decades, NO production becomes research target in biochemical investigations. There are a number of reports using NO levels produced in the macrophage RAW 264.7 cells activated by lipopolysaccharide (LPS) as an excellent model for the screening and subsequent evaluation of the effects of candidate drugs on the inflammatory pathway [3]. Various natural compounds including alkaloids [3], sterols [4], lignans [5], triterpenoids [1, 2] and flavonoids[6] are reported to inhibit NO production in LPS-induced RAW264.7 macrophages, and thus might have potential therapeutic applications in treating a number of inflammatory diseases [7].

Callistemon, belonging to family Myrtaceae, is a genus of about 37 species [8], all of which originated from Australia [9]. Callistemon citrinus (Curtis) Skeels (syn. Callistemon lanceolantus D.C.) [9], local name "Tram bong do", is widely grown in Vietnam as ornaments for its beautiful form, glossy green foliage and year-round, red, bottle-brush like flowers [10]. The tree is used in folk medicine for treatment of influenza and cough [11]. Phytochemical and biological studies of Callistemon species have led to the isolation and characterization of antibacterial acylphloroglucinols [12, 13], anti-staphylococcal neolignans [14], anti-parasitic and anti-insecticidal essential oil [9], along with triterpenoids [15] with elastase inhibition and free radical scavenging activities [16] and flavones with anti-diabetic property [17].

In previous papers, we reported the isolation of acylphloroglucinol derivatives and triterpenoids with soluble epoxide hydrolase inhibitory activity [18] as well as phenolic compounds [19] from Callistemon citrinus leaves and stems. Screening for anti-inflammatory activity revealed that the methanolic crude extract of $C$. citrinus leaves and stems showed inhibitory effect on NO-production in murine RAW264.7 macrophages activated by bacterial lipopolysaccharide (LPS). In this study, we describe the isolation and structural elucidation of active compounds from the chloroform and ethyl acetate fractions of this methanol extract. This resulted in the isolation of seven flavonoids and five triterpenoids including the new callistine A (1) (6-methyl-5,7-dihydroxy-4'-methoxy flavone) and six known flavonoids, 6,7-dimethyl-5,7dihydroxy-4'-methoxy flavone (2), astragalin (3), quercetin (4), catechin (5), eucalyptin (6), and 8-demethyleucalyptin (7), along with $3 \beta$-acetylmorolic acid (8), 3 $\beta$-hydroxy-urs-11-en-13(28)olide (9), betulinic acid (10), diospyrolide (11) and ursolic acid (12). The structures of the compounds were elucidated by spectroscopic methods including 1D- and 2D-NMR and ESI-MS. Our investigation showed that among investigated compounds, quercetin (4) and $3 \beta$-hydroxyurs-11-en-13(28)-olide (9) are the most potent anti-inflammatory compounds as shown by their activities against NO production in LPS-stimulated murine RAW264.7 macrophages.

\section{MATERIALS AND METHODS}

\subsection{General experimental procedures}

${ }^{1} \mathrm{H}-\mathrm{NMR}(500 \mathrm{MHz}),{ }^{13} \mathrm{C}$ NMR $(125 \mathrm{MHz})$ spectra were measured on a Bruker AVANCE 500 spectrometer. The ESI-MS spectra were obtained with a ESI-MicroQ-TOF III (Bruker Daltonics Inc.) and a FT-ESI-MS (Varian Inc.) mass spectrometer. UV and IR spectra were obtained on a JASCO V-630 and an Impact 410 Nicolet FT-IR spectrometer, respectively. Column chromatography (CC) was carried out on silica gel ( $\mathrm{Si} 60 \mathrm{~F}_{254}, 230-400$ mesh, Merck). All solvents were distilled before use. Precoated plates of silica gel $60 \mathrm{~F}_{254}$ were used for analytical purposes. Compounds were visualized under UV radiation $(254,365 \mathrm{~nm})$ and by spraying plates with $10 \% \mathrm{H}_{2} \mathrm{SO}_{4}$ followed by heating with a heat gun.

\subsection{Plant material}


The leaves and stems of Callistemon citrinus (Curtis) Skeels were collected in Hue province, Vietnam. The plants were identified by the botanist Dr. Tran The Bach (Institute of Ecology and Biological Resources, VAST). A voucher specimen (HCTN-2118) is deposited in the herbarium of the Institute of Natural Products Chemistry, VAST, Hanoi, Vietnam.

\subsection{Extraction and isolation}

Dried powdered leaves and stems of $C$. citrinus $(3.2 \mathrm{~kg}$ ) were extracted with $\mathrm{MeOH}$ over the period of 5 days at room temperature and concentrated under reduced pressure to yield a black crude $\mathrm{MeOH}$ extract $(190 \mathrm{~g})$. This crude $\mathrm{MeOH}$ extract was suspended in hot $\mathrm{MeOH}-$ water $(1: 1, \mathrm{v} / \mathrm{v})$ and successively partitioned with $n$-hexane, dichloromethane (DCM), ethyl acetate (EtOAc) and water. The resulting fractions were concentrated under reduced pressure to give the corresponding solvent-soluble fractions $n$-hexane (27.3 g), DCM (63.0 g), EtOAc (55.4 $\mathrm{g}$ ), and water.

The DCM fraction $(63.0 \mathrm{~g})$ was subjected to CC on flash silica gel column $(400-630$ mesh) with gradient solvents of DCM - methanol (1:0, 40:1, 20:1, 10:1, 5:1, 2.5:1, 1:1 and 0:1, $\mathrm{v} / \mathrm{v}, 1.5 \mathrm{~L}$ each) to afford 6 fractions (Fr. D1 to D6). The fraction D1 (10.2 g) was subjected to a silica gel CC, eluting with an isocratic solvent mixture of $n$-hexane-DCM-acetone (1:2:0.1, $\mathrm{v} / \mathrm{v} / \mathrm{v}$ ), to afford 12 fractions (D1A to D1L). The fraction D1J was chromatographed on a silica gel column (400-630 mesh), and eluted with $n$-hexane-acetone $(5: 1, \mathrm{v} / \mathrm{v})$ to afford 3 fractions (D1J1 to D1J3). The fraction D1J1 was filtered and washed with $n$-hexane, recrystaled in $n$ hexane-EtOAc $(1: 1, \mathrm{v} / \mathrm{v})$ to obtain compounds 1 and $2(17.9 \mathrm{mg})$ in mixture. The fraction D1C $(3.8 \mathrm{~g})$ was eluted with $n$-hexane - DCM $(1: 3, \mathrm{v} / \mathrm{v})$ on a silica gel column $(230-400$ mesh) to yield compound $7(6.1 \mathrm{mg})$. The fraction D1-D $(2.5 \mathrm{~g})$ was chromatographed on a silica gel CC using a solvent mixture of $n$-hexane-acetone $(6: 1, \mathrm{v} / \mathrm{v})$ to produce two fractions D1D1 and D1D2. The subfraction D1D1 (1.0 g) was rechromatographed over a YMC RP-18 column using acetone-MeOH $(1: 2, \mathrm{v} / \mathrm{v})$ to yield compound $8(18.3 \mathrm{mg})$. The fraction D1G $(1.2 \mathrm{~g})$ was subjected for CC on silica gel with solvent mixture $n$-hexane-acetone $(5 / 1, \mathrm{v} / \mathrm{v})$ to afford 4 fractions (D1G1 to D1G4). The fraction D1G4 $(80.0 \mathrm{mg})$ was further chromatographed on a silica gel column with $n$-hexane-EtOAc-MeOH $(4: 1: 0.1, \mathrm{v} / \mathrm{v} / \mathrm{v})$ as eluting solvent to afford 2 sub-fractions (D1G4-A and -B). Precipitate fallen out in the sub-fraction D1G4-B was filtered, washed by $n$-hexane and $\mathrm{MeOH}(2 \times 1 \mathrm{ml})$ to yield pure compound 11(10.4 mg). The fraction D1-I was further purified on a silica gel CC using $n$-hexane-EtOAc $(3: 1, \mathrm{v} / \mathrm{v})$ to afford 2 subfractions D1I-A and D1I-B. The sub-fraction D1I-A (29.2 mg) was subjected on a silica gel CC eluting with solvent mixture $\mathrm{CHCl}_{3}$-acetone $(15: 1, \mathrm{v} / \mathrm{v})$ to give compound $9(18.5 \mathrm{mg})$. The fraction D4 was subjected on a silica gel CC using $n$-hexane-acetone $(3: 1, \mathrm{v} / \mathrm{v})$ to afford 2 fractions D4-A and -B. The fraction D4-A was purified by silica gel CC using a solvent mixture of $\mathrm{CH}_{2} \mathrm{Cl}_{2}$-EtOAc $(4: 1, \mathrm{v} / \mathrm{v})$ to afford compounds $\mathbf{1 0}(79.0 \mathrm{mg})$ and $\mathbf{1 2}(60.0 \mathrm{mg})$.

The EtOAc fraction $(55.4 \mathrm{~g})$ was chromatographed on a flash silica gel column $(400-630$ mesh, Merck) with gradient solvents of DCM - methanol (1:0, 40:1, 20:1, 10:1, 5:1, 2.5:1, 1:1 and 0:1, v/v, $1.5 \mathrm{~L}$ each) to produce 7 fractions (Fr. E1 to E7). The fraction E4 (21.8 g) was separated on a silica gel column, eluting with a gradient of chloroform-methanol-water (4:1:0.1 $\div 3: 1: 0.1, \mathrm{v} / \mathrm{v} / \mathrm{v}$ ), to afford 06 fractions (E4A to E4F). The fraction $\mathrm{E} 4 \mathrm{C}$ was was subjected on a silica gel CC, eluting with a solvent mixture of acetone-chloroform-water $(2: 1: 0.1, \mathrm{v} / \mathrm{v} / \mathrm{v})$ to afford 6 subfractions (Fr. E4C-1 to E4C-6). The fraction E4C-3 (0.5 g) was further chromatographed on a silica gel column using a solvent mixture of chloroform-methanol-water $(4: 1: 0.1, \mathrm{v} / \mathrm{v} / \mathrm{v})$ to yield compound $\mathbf{3}(11.7 \mathrm{mg})$. The fraction E3 $(1.1 \mathrm{~g})$ was subjected on a silica gel column chromatography, eluting with a $\mathrm{CH}_{2} \mathrm{Cl}_{2}-\mathrm{MeOH}(15: 1$, v/v) to afford 2 fractions E3A 
and E3B. The fraction E3B $(0.55 \mathrm{~g})$ was further separated on a silica gel column chromatography, eluting with a mixture of $n$-hexane- $\mathrm{Me}_{2} \mathrm{CO}(2: 1, \mathrm{v} / \mathrm{v})$, to yield compound 4 (11.9 mg). The fraction E4C1 was rechromatographed over a RP-18 column, eluting with $\mathrm{MeOH}-\mathrm{H}_{2} \mathrm{O}$ (1:1) to afford 4 sub-fractions (C1A to $\left.\mathrm{C} 1 \mathrm{D}\right)$. The sub-fraction $\mathrm{C} 1 \mathrm{~A}$ was rechromatographed over a RP-18 column eluting with $\mathrm{MeOH}-\mathrm{H}_{2} \mathrm{O}(1: 3, \mathrm{v} / \mathrm{v})$ to yield compound 5 (46.0 mg).

The $n$-hexane fraction $(27.0 \mathrm{~g})$ was chromatographed on a silica gel column, using $n$ hexane - EtOAc (1:0, 40:1, 20:1, 10:1, and 5:1, v/v, 1.0 L each) to afford 5 fractions (A1 to A5). The fraction H4 was rechromatographed on silica gel column, eluting with DCM - EtOAc (20:1, $\mathrm{v} / \mathrm{v})$ to yield compound $\mathbf{6}(11 \mathrm{mg})$.

\subsection{Spectral and physical data}

2.4.1 Callistine A (6-methyl-5,7-dihydroxy-4'-methoxy flavone) (1) yellow solid, soluble in $\mathrm{MeOH}$ and chloroform. $R_{f}=0.50$ in dichloromethane $/ \mathrm{EtOAc}, 6 / 1 . \mathrm{C}_{17} \mathrm{H}_{14} \mathrm{O}_{5}(\mathrm{MW}=298) .{ }^{1} \mathrm{H}-$ NMR (500 MHz, DMSO- $d_{6}$ ) $\delta_{\mathrm{H}}: 6.83$ (s, H-3), 13.14 (s, 5-OH), 1.97 (s, 6-Me), 13.07 (s, 7-OH), 6.55 (s, H-8), 8.00 (d, $\left.J=8.5 \mathrm{~Hz}, \mathrm{H}-2^{\prime}\right), 7.08$ (d, $J=8.5 \mathrm{~Hz}, \mathrm{H}-3$ '), 3.84 (s, 4'-OMe), 7.08 (d, $J=$ $8.5 \mathrm{~Hz}, \mathrm{H}-5$ ) $), 8.00$ (d, $\left.J=8.5 \mathrm{~Hz}, \mathrm{H}-66^{\prime}\right) .{ }^{13} \mathrm{C}-\mathrm{NMR} \delta_{\mathrm{C}}: 162.9(\mathrm{C}-2), 103.1(\mathrm{C}-3), 181.7$ (C-4), 158.4 (C-5), 106.8 (C-6), 8.2 (6-Me), 162.1 (C-7), 93.0 (C-8), 154.9 (C-9), 103.4 (C-10), 122.9 (C-1'), 128.1 (C-2'), 114.5 (C-3'), 162.1 (C-4'), 55.5 (4'- OMe), 114.5 (C-5'), 128.1 (C-6'). HRESI-MS (m/z): $299.0844[\mathrm{M}+\mathrm{H}]^{+}$(calcd for $\left.\mathrm{C}_{17} \mathrm{H}_{15} \mathrm{O}_{5}, 299.0914\right)$.

2.4.2. 6,8-dimethyl-5,7-dihydroxy-4'-methoxy flavone (2): yellow solid, soluble in $\mathrm{MeOH}$ and chloroform. $R_{f}=0.50$ in dichloromethane / EtOAc 6/1. $\mathrm{C}_{18} \mathrm{H}_{16} \mathrm{O}_{5}(\mathrm{MW}=312) .{ }^{1} \mathrm{H}-\mathrm{NMR}(500$ MHz, DMSO- $\left.d_{6}\right) \delta_{\mathrm{H}}: 6.83(\mathrm{~s}, \mathrm{H}-3), 13.07$ (s, 5-OH), 2.04 (s, 6-Me), 2.27 (s, 8-Me), 8.00 (d, $J=$ $\left.8.5 \mathrm{~Hz}, \mathrm{H}-2^{\prime}\right), 7.08$ (d, J =8.5 Hz, H-3'), 3.84 (s, 4'-OMe), 7.08 (d, $\left.J=8.5 \mathrm{~Hz}, \mathrm{H}-5^{\prime}\right), 8.00$ (d, $J=$ $8.5 \mathrm{~Hz}, \mathrm{H}-6$ '). ${ }^{13} \mathrm{C}-\mathrm{NMR} \delta_{\mathrm{C}}: 163.0(\mathrm{C}-2), 103.4(\mathrm{C}-3), 182.1$ (C-4), $156.0(\mathrm{C}-5), 107.0(\mathrm{C}-6), 7.3$ (6-Me), 159.7 (C-7), 101.8 (C-8), 8.0 (8-Me), 152.4 (C-9), 103.6 (C-10), 123.2 (C-1'), 128.2 (C2'), 114.6 (C-3'), 162.1 (C-4'), 55.5 (4'- OMe), 114.6 (C-5'), 128.2 (C-6'). HR-ESI-MS: m/z $311.0947[\mathrm{M}-\mathrm{H}]^{-}\left(\right.$Calcd for $\left.\mathrm{C}_{18} \mathrm{H}_{15} \mathrm{O}_{5}, 311.1000\right)$.

\subsection{NO inhibitory activity}

The assay for NO inhibitory activity was conducted according to procedures previously described in the literature [1]. RAW 264.7 macrophages (ATCC, Manassas, VA, USA)-were cultured on $100 \mathrm{~mm}$ culture dishes in DMEM supplemented with $10 \%$ FBS (fetal bovine serum), penicillin $(100 \mathrm{UI} / \mathrm{ml})$ and streptomycin $(100 \mu \mathrm{g} / \mathrm{ml})$ at $37^{\circ} \mathrm{C}$ with $5 \% \mathrm{CO}_{2}$. The medium was changed every $48 \mathrm{~h}$. For the NO production inhibitory assay, the cells were harvested in logarithmic phages and seeded into $96-$ well plates $\left(10^{5}\right.$ cells per well). Different concentrations of isolated compounds $(10 ; 20$ and $40 \mu \mathrm{g} / \mathrm{mL})$ were prepared in FBS-free DMEM to give a total volume of $500 \mu \mathrm{L}$ in each well of a microtiter plate. After $1 \mathrm{~h}$ treatment, cells were stimulated with $1 \mu \mathrm{g} / \mathrm{mL}$ of LPS for $24 \mathrm{~h}$. Sulfuretin (Sigma-Aldrich, purity 98.0\%) was used as a positive control. The nitrite concentration in the culture supernatant was determined by the Griess reaction. Briefly, $100 \mathrm{~mL}$ of cell culture medium (without phenol red) was mixed with an equal volume of Griess reagent (equal volumes of $1 \%(\mathrm{w} / \mathrm{v})$ sulfanilamide in $5 \%(\mathrm{v} / \mathrm{v})$ phosphoric acid and $0.1 \%(\mathrm{w} / \mathrm{v})$ naphthylethylenediamine- $\mathrm{HCl})$, incubated at room temperature for $10 \mathrm{~min}$, and then the absorbance was measured at $550 \mathrm{~nm}$ using a microplate reader. Fresh 
culture medium was used as the blank in all experiments. The amount of nitrite in the samples was obtained by means of the $\mathrm{NaNO}_{2}$ serial dilution standard curve and the nitrite production was measured.

\subsection{Cytotoxic assay}

Cell viability of the compounds was measured using MTT (3-(4,5-Dimethythiazol-2-yl)2,5-diphenyl-tetrazolium bromide) (Sigma-Aldrich) assays, where the mitochondrial-dependent reduction of MTT to formazan was used as an indicator of cell viability [1]. Briefly, RAW 264.7 cells were harvested and seeded into 96-well plates at $10^{4}$ cells/well, different concentrations of compounds were added and incubated for $24 \mathrm{~h}$ at $37^{\circ} \mathrm{C}$ and $5 \% \mathrm{CO}_{2}$. The cells growth was quantified by the ability of living cells to reduce the yellow dye MTT to a purple formazan product. At the end of the incubation, $10 \mu \mathrm{L}$ of MTT $(5 \mathrm{mg} / \mathrm{mL}$, in PBS) was added to each well. After incubated for another $3 \mathrm{~h}$, the medium was then removed and the formazan precipitate was dissolved in $150 \mathrm{~mL}$ DMSO. The absorbance was measured at $550 \mathrm{~nm}$ on a microplate reader (BD PharMingen, CA, USA).

\subsection{Statistical Analysis}

All data are presented as means of three replicate determinations \pm standard deviation (SD). In all comparisons, $P<0.05$ was considered significant. The statistical analysis was carried out by analysis of variance (ANOVA) followed by Tukey's test. The data were evaluated with SPSS 20.0 (SPSS Inc., Chicago, IL, USA).

\section{RESULTS AND DISCUSSION}

Compound 1 was isolated as yellow powder. Its molecular formula was determined as $\mathrm{C}_{17} \mathrm{H}_{14} \mathrm{O}_{5}$ from pseudo-molecular peak at $299.0844\left([\mathrm{M}+\mathrm{H}]^{+}\right.$, calcd. for $\mathrm{C}_{17} \mathrm{H}_{15} \mathrm{O}_{5}:$ 299.0919) in HR-ESI-MS spectra. The ${ }^{1} \mathrm{H}-,{ }^{13} \mathrm{C}$ - and DEPT NMR spectra (Table 1) showed the aromatic proton signals characteristic for the 1,4-disubstituted ring B of a flavonoid, at $\delta_{\mathrm{H}} 7.08(2 \mathrm{H}, \mathrm{d}, J=$ $\left.8.5 \mathrm{~Hz}, \mathrm{H}-3^{\prime}, \mathrm{H}-5^{\prime}\right)$ and $8.00\left(2 \mathrm{H}, \mathrm{d}, J=8.5 \mathrm{~Hz}, \mathrm{H}-2^{\prime}, \mathrm{H}-6^{\prime}\right)$. Four singlet signals (each $1 \mathrm{H}$ ) observed at $\delta_{\mathrm{H}} 13.14,13.07,6.83$ and 6.55 were assigned for protons $5-\mathrm{OH}, 7-\mathrm{OH}, \mathrm{H}-3$ and $\mathrm{H}-8$ respectively. The bonding of 6-Me on the quarternary carbon $\mathrm{C}-6\left(\delta_{\mathrm{C}} 106.8\right)$ of the flavonoid ring was confirmed by the HMBC cross-peaks between the methyl group 6-Me $\left(\delta_{\mathrm{H}} 1.97\right)$ and carbons C-5 $\left(\delta_{\mathrm{C}} 158.4\right), \mathrm{C}-6$ (106.8) and C-7 (162.1). Based on the spectroscopic evidences, the structure of 1 has been identified as 6-methyl-5,7-dihydroxy-4'-methoxy flavone (Figure 1). Compound $\mathbf{1}$ is isolated from nature for the first time and is named callistine $\mathrm{A}$.

Compound 2 was isolated as yellow powder in mixture with compound 1. Its molecular formula was determined as $\mathrm{C}_{18} \mathrm{H}_{16} \mathrm{O}_{5}$ from HR-ESI-MS pseudo-molecular ion peak at 311.0947 $[\mathrm{M}-\mathrm{H}]^{-}$(Calcd for $\left.\mathrm{C}_{18} \mathrm{H}_{15} \mathrm{O}_{5}, 311.1000\right)$. The ${ }^{1} \mathrm{H}$ - and ${ }^{13} \mathrm{C}-\mathrm{NMR}$ data of 2 were similar to those of compound 1 except for the presence of an additional methyl group. This methyl group was determined to attach on carbon C-8 of the flavonoid ring system by the HMBC correlations of Me-8 protons $\left(\delta_{\mathrm{H}} 2.27\right)$ to carbons C-7 $\left(\delta_{\mathrm{C}} 159.7\right), \mathrm{C}-8$ (101.8) and C-9 (152.4). From the spectroscopic data, the structure of compound 2 was determined as 6,8-dimethyl-5,7-dihydroxy4'-methoxy flavone, isolated also from Callistemon lanceolatus [17] (Figure 1).

Compounds 3 - 12 (Figure 1) are the known flavonoids astragalin (3) [20], quercetin (4) [21], catechin (5) [16], eucalyptin (6) [22] and 8-demethyleucalyptin (7) [22], and the known 
triterpenoids $3 \beta$-acetylmorolic acid (8) [23], 3 $\beta$-hydroxy-urs-11-en-13(28)-olide (9) [24], betulinic acid (10) [16], diospyrolide (11) [25] and ursolic acid (12) [26], which were found and described by us previously [18]. Their structures were elucidated by comparing their spectral data $\left({ }^{1} \mathrm{H}\right.$ - and ${ }^{13} \mathrm{C}-\mathrm{NMR}$, ESI- and HR-ESI-MS) with those published in literatures.<smiles>[R]c1c(O)c(C)c(O)c2c(=O)cc(-c3ccc(OC)cc3)oc12</smiles><smiles></smiles>

$3 \mathrm{R}_{1}=\mathrm{OGIC} ; \mathrm{R}_{2}=\mathrm{R}_{4}=\mathrm{OH} ; \mathrm{R}_{3}=\mathrm{H}$

$4 \mathrm{R}_{1}=\mathrm{R}_{2}=\mathrm{R}_{3}=\mathrm{R}_{4}=\mathrm{OH}$<smiles>[R]c1c(OC)c(C)c(O)c2c(=O)cc(-c3ccc(OC)cc3)oc12</smiles>

$6 \mathrm{R}=\mathrm{CH}_{3}$

$7 \mathrm{R}=\mathrm{H}$

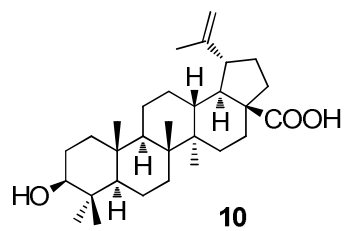

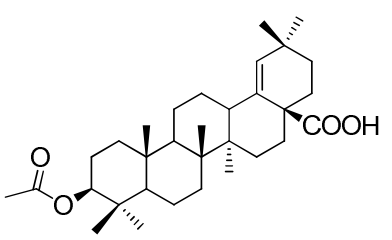

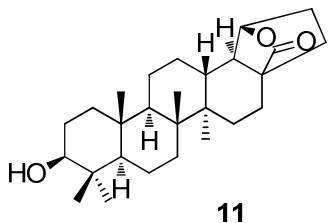<smiles>Oc1cc(O)c2c(c1)OC(O)C(c1ccc(O)c(O)c1)O2</smiles>

5

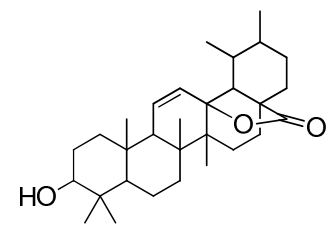

9

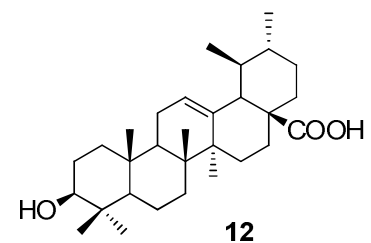

Figure 1. Flavonoids and triterpenoids isolated from Callistemon citrinus leaves and stems.

All isolated compounds (1-12) were assayed for cytotoxic effects and NO inhibitory activity. In the MTT assays for cytotoxic effects, all isolated compounds (1-12), LPS (at tested concentration of $1 \mu \mathrm{g} / \mathrm{ml}$ ) and sulfuretin did not affect the cell viability of RAW 264.7 cells (data not shown). The isolated compounds (1-12) inhibited the NO production in LPS-induced RAW264.7 macrophages in a dose-dependent manner.

As shown in Figure 2, at $10 \mu \mathrm{M}$ the inhibitory effect on NO production of the flavonoids 3 7 are as follows: eucalyptin $(\mathbf{6})(9.3 \%)<$ catechin $(\mathbf{5})(9.2 \%)<$ callistin A/B (1/2) $(31.8 \%)<8$ demethyleucalyptin (7) $(32.1 \%)<$ astragalin (3) $(34.6 \%)<$ quercetin (4) $(57.3 \%)$. At $20 \mu \mathrm{M}$, quercetin (4) and catechin (5) decreased approximately $50 \%$ of the LPS-induced NO production by 80 and $61.8 \%$, respectively. Among all testing flavonoids, quercetin (4) showed the most notable NO-production inhibitory effect with $57.3 \% ; 80.0 \%$ and $91.6 \%$ inhibition at increasing testing concentration of 10,20 and $40.0 \mu \mathrm{M}$, respectively. 


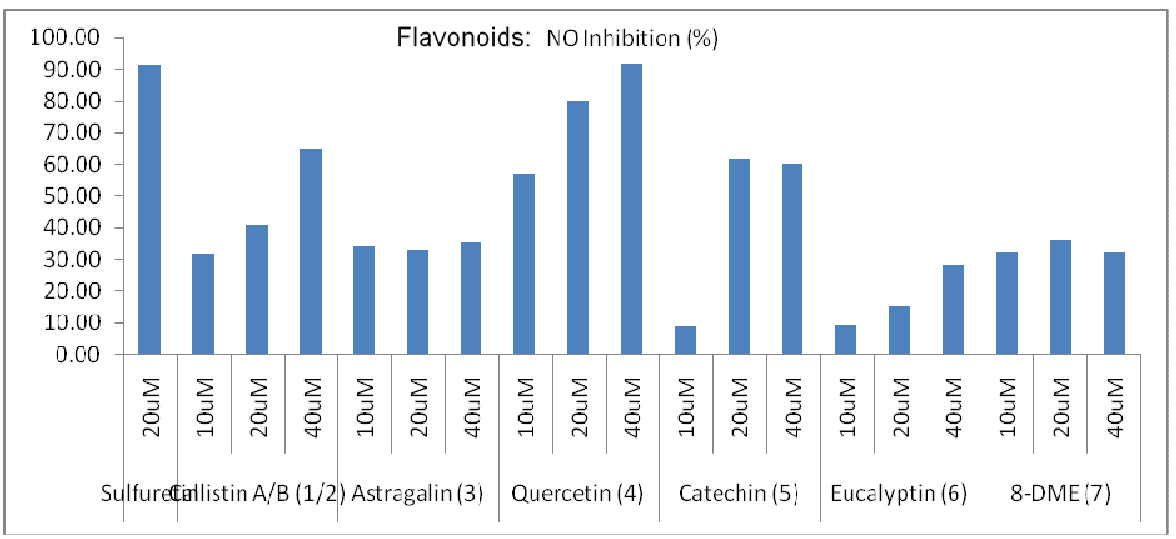

Figure 2. Inhibitory effects of flavonoids isolated from C.citrinus on NO production $(\mathrm{n}=3)$.

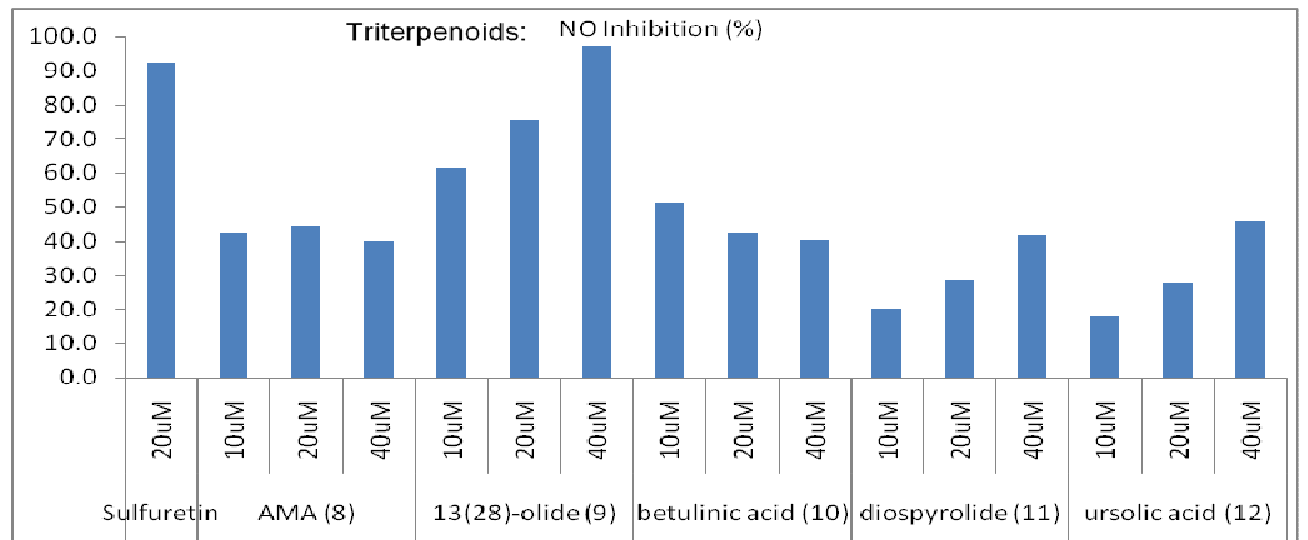

Figure 3. Inhibitory effects of triterpenoids (b) isolated from C.citrinus on NO production $(\mathrm{n}=3)$.

Figure 3 shows the inhibitory effects of the triterpenoids $\mathbf{8}-\mathbf{1 2}$ against NO production. Activities were found to be in this order: $3 \beta$-hydroxy-urs-11-en-13(28)-olide (9) $>$ betulinic acid (10) $>3 \beta$-acetylmorolic acid (8) > diospyrolide (11) $>$ ursolic acid (12). Compound 9 showed the most remarkable inhibitory effect against NO production with inhibition of $61.5 \%, 72.4 \%$ and $97.2 \%$ at concentrations 10, 20 and $40.0 \mu \mathrm{M}$, respectively. Compound (9) has been previously isolated from Pieris japonica [27] and Isodon loxothyrsus [28], but this is the first report about its anti-inflammatory activity.

\section{CONCLUSION}

Phytochemical investigation of the leaves and stems of Callistemon citrinus (Curtis) Skeels led to the isolation of one new flavonoid named callistine A (1) and six known flavonoids, 6,7dimethyl-5,7-dihydroxy-4'-methoxy flavone (2), astragalin (3), quercetin (4), catechin (5), eucalyptin (6), and 8-demethyleucalyptin (7), along with 5 known triterpenoids, 3- $\beta$ acetylmorolic acid (8), 3 $\beta$-hydroxy-urs-11-en-13(28)-olide (9), betulinic acid (10), diospyrolide (11) and ursolic acid (12). Their chemical structures were determined by analysis of their 1Dand 2D-NMR and HR-MS data. Among isolated compounds, quercetin (4) and $3 \beta$-hydroxy-urs- 
11-en-13(28)-olide (9) showed potential inhibition activity against NO production in LPSstimulated RAW264.7 cells.

Acknowledgement. This research was part of the Vietnam-Korea Project (Code 52/2011/NĐT) supported by Vietnam Ministry of Science and Technology (MOST).

\section{REFERENCES}

1. Nhiem N. X., Tai B. H., Quang T. H., Kiem P. V., Minh C. V., Nam N. H., Kim J. H., Im L. R., Lee Y. M. and Kim Y. H. - A new ursane-type triterpenoid glycoside from Centella asiatica leaves modulates the production of nitric oxide and secretion of TNF-alpha in activated RAW 264.7 cells, Bioorg. Med. Chem. Lett. 21 (2011) 1777-1781.

2. Tung N. T., Cuong T. D., Hung T. M., Lee J. H., Woo M. H., Choi J. S., Kim J., Ryu S. H. and Min B. S. - Inhibitory effect on NO production of triterpenes from the fruiting bodies of Ganoderma lucidum, Bioorg. Med. Chem. Lett. 23 (2013) 1428-1432.

3. Park J. E., Cuong T. D., Hung T. M., Lee I., Na M., Kim J. C., Ryoo S., Lee J. H., Choi J. S., Woo M. H. and Min B. S. - Alkaloids from Chelidonium majus and their inhibitory effects on LPS-induced NO production in RAW264.7 cells, Bioorg. Med. Chem. Lett. 21 (2011) 6960-6963.

4. Li W., Zhou W., Cha J. Y., Kwon S. U., Baek K. H., Shim S. H., Lee Y. M., and Kim Y. H. - Sterols from Hericium erinaceum and their inhibition of TNF- $\alpha$ and NO production in lipopolysaccharide-induced RAW 264.7 cells, Phytochemistry 115 (2015) 231-238.

5. Fang L., Xie C., Wang H., Jin D. Q., Xu J., Guo Y. and Ma Y. - Lignans from the roots of Kadsura coccinea and their inhibitory activities on LPS-induced NO production, Phytochemistry Lett. 9 (2014) 158-162.

6. Xie C., Kang J., Li Z., Schauss A.G., Badger T. M., Nagarajan S., Wu T. and Wu X. - The açaí flavonoid velutin is a potent anti-inflammatory agent: blockade of LPS-mediated TNF- $\alpha$ and IL-6 production through inhibiting NF- $\kappa$ B activation and MAPK pathway, J. Nut. Biochem. 23 (2012) 1184-1191.

7. Lee E., Jeong K. W., Shin A. and Kim Y. - Anti-inflammatory activity of 3,6,3'trihydroxyflavone in mouse macrophages, in vitro, Bull. Korean Chem. Soc. 35 (2014) 3169-3174.

8. The Plant List (2010). Version 1. Published on the Internet; http://www.theplantlist.org/ (accessed on $1^{\text {st }}$ January 2015).

9. Goyal P. K., Jain R., Jain S. and Sharma A. - A Review on biological and phytochemical investigation of plant genus Callistimon, Asian Pac. J. Trop.Biomed. 2 (2012) S1906S1909.

10. Pham Hoang Ho - An Illustrated Flora of Vietnam Vol. II. Youth Publisher, Hanoi, Vietnam, p. 66 (2000).

11. Lee J., Bach T. T., Canh L. X., Joung H. - Useful flowering plants in Vietnam, CRESEED Co. Ltd., Daejeon, Republic of Korea, 2011.

12. Rattanaburi S., Mahabusarakam W., Phongpaichit S. and Carroll A. R. Acylphloroglucinols from Callistemon lanceolatus DC, Tetrahedron 69 (2013) 60706075 . 
13. Khambay B. P. S., Beddie D. G., Hooper A. M., Simmonds M. S. J. and Green P. W. C. New Insecticidal Tetradecahydroxanthenediones from Callistemon viminalis, J. Nat. Prod. 62 (1999) 1666-1667.

14. Rattanaburi S., Mahabusarakam W., Phongpaichit S. and Carroll A. R. - Neolignans from Callistemon lanceolatus, Phytochemistry Lett. 5 (2012) 18-21.

15. Jeong W., Hong S. S., Kim N., Yang Y. T., Shin Y. S., Lee C., Hwang B. Y. and Lee D. Bioactive triterpenoids from Callistemon lanceolatus, Arch. Pharm. Res. 32 (2009) 845849.

16. Kim J. H., Byun J. C., Bandi A. K. R., Hyun C. G., and Lee N. H. - Compounds with elastase inhibition and free radical scavenging activities from Callistemon lanceolatus, J. Med. Plants Res. 3 (2009) 914-920.

17. Nazreen S., Kaur G., Alam M.M., Shafi S., Hamid H., Ali M. and Alam M. S. - New flavones with antidiabetic activity from Callistemon lanceolatus DC, Fitoterapia 83 (2012) 1623-1627.

18. Khanh P. N., Duc H. V., Huong T. T., Son N. T., Ha V. T., Van D. T., Tai B. H., Kim J. E., Kim Y. H., and Cuong N. M. - Acylphloroglucinol derivatives and triterpenoids with soluble epoxide hydrolase inhibitory activity from Callistemon citrinus, Fitoterapia (submitted) (2015).

19. Khanh P. N., Duc H. V., Huong T. T., Ha V. T., Van D. T., Son N. T., Kim Y. H., Viet D.K., Cuong N. M. - Phenolic compounds from Callistemon citrinus leaves and stems, J. Sci. Tech. 54 (2) (2016) 190.

20. Deng S., Deng Z., Fan Y., Peng Y., Li J., Xiong D. and Liu R. - Isolation and purification of three flavonoid glycosides from the leaves of Nelumbo nucifera (Lotus) by high-speed counter-current chromatography, J. Chromatography B 877 (2009) 2487-2492.

21. Shen C. C., Chang Y. S., and Hott L. K. - Nuclear magnetic resonance studies of 5,7dihydroxyflavonoids, Phytochemistry 34 (1993) 843-845.

22. Sidana J., Neeradi D., Choudhary A., Singh S., Foley W. J., and Singh I. P. Antileishmanial polyphenols from Corymbia maculata, J. Chem. Sci. 125 (2013) 765775 .

23. González A. G., Fraga B. M., González P., Hernandez M. G., and Ravelo A. G. $-{ }^{13}$ C NMR spectra of olean-18-ene derivatives, Phytochemistry 20 (1981) 1919-1921.

24. Katai M., Terai T. and Meguri H. - Triterpenoids of the Bark of Pieris japonica D. DON. (Japanese Name: Asebi). II. ${ }^{13} \mathrm{C}$-NMR of the $\gamma$-Lactones of ursane- and oleanane-type triterpenes, Chem. Pharm. Bull. 31 (1983) 1567-1571.

25. Kuo Y. H. and Chang C. I. - Six new compounds from the heartwood of Diospyros maritima, Chem. Pharm. Bull. (Tokyo) 48 (2000) 1211-1214.

26. Keat N. B., Umar R. U., Lajis N. H., Chen T. Y., Li T. Y., Rahmani M., and Sukari M. A. - Chemical constituents from two weed species of Spermacoce (Rubiaceae), Malaysian J. Anal. Sci. 14 (2010) 6-11.

27. Katai M., Terai T. and Meguri H. - Triterpenoids of the Bark of Pieris japonica D. DON, Chem. Pharm. Bull. 29 (1981) 261-264.

28. Hao H., Han-Dong S., Shou-Xun Z. - Triterpenoids of Isodon loxothyrsus, Phytochemistry 42 (1996) 1665-1666. 


\section{TÓM TẮT}

\section{CÁC HỢP CHÂT FLAVONOID VÀ TRITERPENOID PHÂN LẬP TỬ LÁ VÀ CÀNH LOÀI CALLISTEMON CITRINUS VÀ TÁC DƯNG ỨC CHẾ CỦA CHÚNG ĐỐI VỚI SỬ SẢN SINH NO TRÊN DÒNG ĐẠI THỰC BÀ̃O RAW264.7 BI KÍCH THÍCH VIÊM BỞI LPS}

Nguyễn Mạnh Cường ${ }^{1}$, Phạm Ngọc Khanh ${ }^{1}$, Hồ Việt Đức ${ }^{2}$, Trần Thu Hường ${ }^{1}$, Youn-Chul Kim ${ }^{3}$, Phạm Quốc Long ${ }^{1}$, Young Ho Kim ${ }^{4}$

${ }^{I}$ Viện Hóa học các hơp chất thiên nhiên, Viện Hàn lâm Khoa học và Công nghệ Việt Nam, 18 Hoàng Quốc Việt, Cầu Giấy, Hà Nội

${ }^{2}$ Khoa Dược, Trường Đại học Y Dược Huế, Đại học Huế, 06 Ngô Quyền, Huế, Việt Nam

${ }^{3}$ Khoa Duợc, Trường Đại hoc Wonkwang, Iksan 570-749, Korea

${ }^{4}$ Khoa Dược, Truờng Đại học Quốc gia Chungnam, Daejeon 305-764, Hàn Quốc

Từ các phân đoạn $n$-hexane, dichloromethane và EtOAc của lá và cành loài Tràm bông đỏ Callistemon citrinus (Curtis) Skeels đã phân lập và xác định được cấu trúc của 12 hợp chất flavonoid và triterpenoid, bao gồm một hợp chất flavonoid mới là callistine $\mathrm{A}(\mathbf{1})$, sáu flavonoid đã biết là 6,7- dimethyl-5,7-dihydroxy-4'-methoxy flavone (2), astragalin (3), quercetin (4), catechin $(\mathbf{5})$, eucalyptin $(\mathbf{6})$, và 8 -demethyleucalyptin $(7)$, cùng với 5 triterpenoid là $3-\beta$ acetylmorolic acid (8), 3 $\beta$-hydroxy-urs-11-en-13(28)-olide (9), betulinic acid (10), diospyrolide (11) và ursolic acid (12). Cấu trúc hóa học của các hợp chất trên được xác định nhờ các phương pháp hóa lý và các phương pháp phổ bao gồm phổ cộng hưởng từ nhân 1 chiều, 2 chiều và phổ khối lượng. Tác dụng kháng viêm in vitro của các hợp chất (1-12) được nghiên cứu trên cơ sở xác định hoạt tính ức chế sự sản sinh NO trên dòng đại thực bào RAW264.7 bị kích thích gây viêm bởi lipopolysaccharide phân lập từ vi khuẩn. Kết quả cho thấy hoạt tính của các hợp chất quercetin (4) và $3 \beta$-hydroxy-urs-11-en-13(28)-olide (9) là đáng chú ý nhất.

Tù̀ khóa: Callistemon citrinus (Curtis) Skeels, flavonoit, triterpenoit. 